\title{
TELEVISION REVIEW
}

\section{Black Holes- Authorised Version}

Quick on the heels of October's Horizon programme about black holes, the BBC last week presented Not Seeing Is Believing, a fifty-minute lecture about black holes by Dennis Sciama of Oxford University. The Horizon programme (see Nature, 245, 467; 1973) should really have been billed as a programme about gravity in general. Black holes were not mentioned until near the end, when the presenter, John Taylor of King's College, London, was seen draped over flagstones bordering the ornamental pond at Herstmonceux, uttering profound thoughts about black holes in this Universe being white holes in the next, and so on.

Anyone left mystified by John Taylor (and there must have been many) should have turned to Dennis Sciama for a clear account of the basics-what black holes are, why astronomers think black holes should exist, how we might look for them, and their generally-agreed properties. But it was strictly for aficionados of astronomy; right at the beginning we had supernovae, radio galaxies, and quasars, without any definitions at all, and soon we were on toevent horizons and the language of the astrophysicist.
On top of that there is the difficulty of turning a lecture into good television. Sciama was speaking before an audience of students at St Andrews Universitynot in an intimate lecture theatre, like the cosy one at the Royal Institution in London that has often been used by the $\mathrm{BBC}$, but in one of those places with a long demonstration bench in front of an array of blackboards.

This problem was overcome by illustrating the lecture with animated drawings projected onto a huge screen above the speaker. These moving drawings were accompanied by a recorded commentary by Dr Sciama, in a more tranquil tone than his lecture theatre voice, that nicely broke up the forceful delivery of the rest of the lecture. The animated drawings -actually not much more complicated than blackboard sketchesthemselves contributed a lot to the programme. We saw matter being swept into black holes, gravitational waves being emitted as a star collapsed, and two black holes coalescing, each developing a proboscis like a Gerald Scarfe cartoon of Edward Heath's nose. It was a neat way of coping with the lecture format, and the white drawings on the black background of the screen seemed particularly appropriate for theoretical astrophysics.
The programme was altogether a very creditable performance. It was presented by the Open University in conjunction with the Royal Astronomical Society, and shown during the Open University's television time. It is, however, very much the kind of programme that graduates of Patrick Moore's latenight astronomy programme would appreciate.

It is also good to see the Royal Astronomical Society taking a part in bringing the excitement of modern astronomy before the public. The society has recently become interested in astronomy education, and this lecture is meant to be the first of a series of public expositions on modern developments in astronomy, the society suggesting the topic, supplying the speaker, and paying his fee. The Royal Astronomical Society is perhaps the most entrancing of the scientific societies in London, even allowing for the transfer of its meetings from its own lecture room in Burlington House to the more cosy but less magical Scientific Societies Lecture Theatre in Saville Row; it has an enthralling history, and its members are carrying out some of the most exciting research work that is going on today. The society ought to be better known to the public.

EDWARd Phillips

\section{COR RESPONDENCE}

\section{Open Journal}

SiR,-May I suggest for Nature a radical, healthy change in what I regard as an essentially ailing magazine (not a journal, while present policies persist)? You say (Nature, 244, 475; 973) "Nature must be an open journal, reflecting the sense of community which is very strong among scientists.". If you mean what you say, my advice is that you should sign your editorials, strip the sobriquets from your coyly labelled "Cell Biology Correspondent", etc., and publish a masthead. Then we can start talking about an open journal.

The snide sharpshooting from behind shields of anonymity, which has become so characteristic of Nature that it is now known in many circles as $\mathrm{Ill}$ Nature, is, I am convinced, a direct result of a smug journalistic tradition of anonymity which is totally out of place in a scientific publication and which other scientific journals have long abandoned. Do you in fact stand behind your own "fine words"? Are you a man, a mouse, or a gnome? How can we tell, when you don't even tell us your name? Are we mortals who have names to conclude you're God? Or that you think you are? Do you dare to print this letter? At least you know who it comes from, since I am not afraid to sign myself

\section{F. Peter Woodford}

\section{Akenside Road,} London NW3 $5 B S$

Nature will have a masthead in January. Full biographical details appeared earlier this year $(243,110 ; 1973)$ from which readers may care to deduce more about my personality. They may also assume that I write the leaders in constructing their identikit of me.-ED.

\section{Arginine Deficiency}

SIR,--In the background information to the discussion on orotic aciduria and arginine deficiency, Milner and Visek stated $^{1}$ that Scull and Rose had shown ${ }^{2}$ that "the growing rat . . . requires arginine for optimum nitrogen retention and normal growth." In point of fact, Scull and Rose had concluded ${ }^{2}$ that arginine was not required by the rat. The initial data on the essential nature of arginine were based on studies with chicks ${ }^{3}$.

Yours faithfully,

\section{A. ARNOLD}

Rensselaer, New York

1 Milner, J. A., and Visek, W. J., Nature, 245, 211 (1973).

${ }^{2}$ Scull, C. W., and Rose, W. C., J. biol. Chem., 89, 109 (1930)

3 Arnold, A., Kline, O. L., Elvehjem, C. A. and Hart, E. B., J. biol. Chem., 116, 699 (1936)

A list of books received will appear in the January 4 issue of Nature. 